stopped at the position where Neumann and Densmore ${ }^{1}$ found this high temperature. At $21^{\circ} 21 \cdot 5^{\prime} \mathrm{N}$., $38^{\circ}$ $04 \cdot 5^{\prime}$ E., Station 42-Atlantis II, samples of high-temperature, highsalinity water were obtained close to the bottom.

Fig. 1 gives the profile of salinity distribution from the Gulf of Suez to the Straits of Bab'd El Mandeb as determined from the R.V. Atlantis II during July 1963. At Station 42 in the deepest part of the section, 1,931-1,978 m., the water was found to be $25.76^{\circ}, 3.5^{\circ}$ warmer than the rather homothermal water above it. Its salinity was $43 \cdot 18$ parts per thousand, 2.4 parts greater than the surroundings immediately over this band of anomalous water (approximately $50 \mathrm{~m}$ thick). Fig. 2 gives the vertical distribution of temperature and salinity for Station 42 .

(More recently the British R.R.S. Discovery has sampled even deeper depths, $2,400 \mathrm{~m}$, in the neighbouring area and has found clear indications of mixtures of normal Red Sea water and the hot salty water from

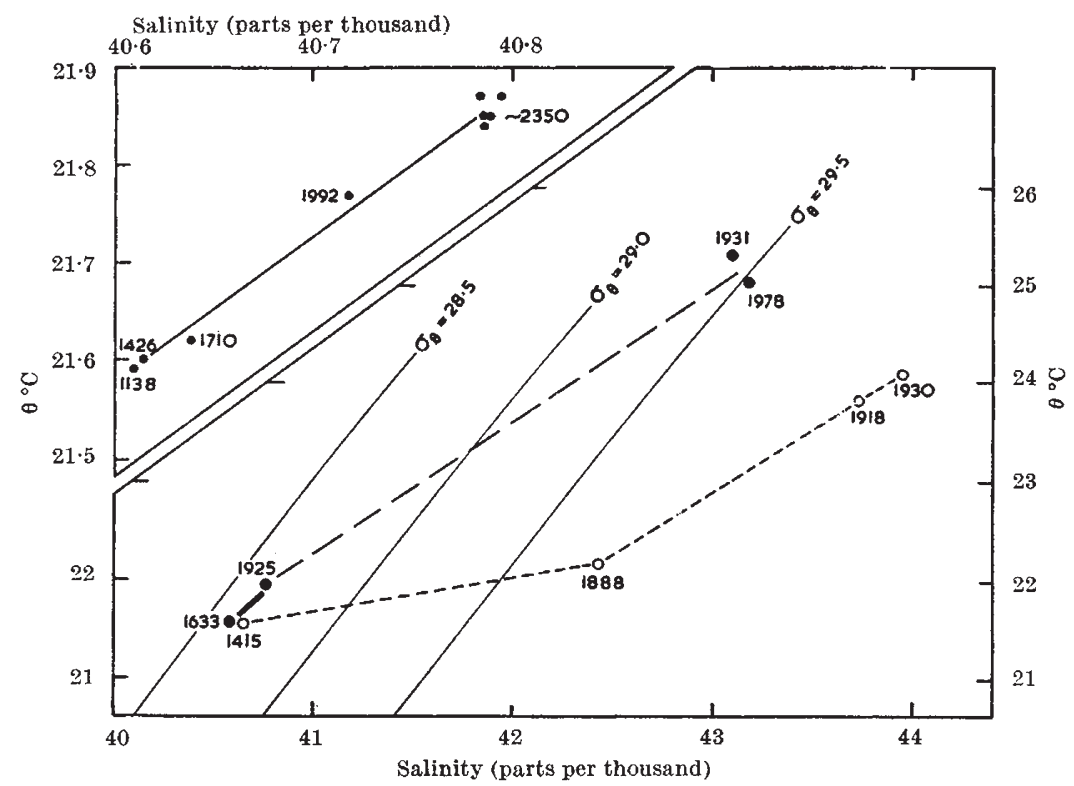

Fig. 1. Potential temperature/salinity diagram for hydrographic stations in the Red Sea. Upper left: Discovery 5247; $21^{\circ} 07^{\prime}$ N., $38^{\circ} 10^{\prime}$ E.; March 1, 1964; lower right: O, Albatross 254 $21^{\circ} 10^{\prime}$ N., $38^{\circ} 09^{\prime}$ E.; May 3, 1948; O, Atlantis $I 142 ; 21^{\circ} 21^{\prime}$ N., $38^{\circ} 05^{\prime}$ E.; August 1,1963 -, Discovery 5247. The figures by the points are depths in metres. The potential density lines are approximate, being extrapolated from Knudsen's formula Station 42.)

Cruise 8 of R.V. Atlantis II was sponsored by grant NSF-GP821 from the U.S. National Science Foundation.

Woods Hole Oceanographic Institution Arthur R. Mrliter Woods Hole,

Mass.

${ }^{3}$ Neumann, A. C., and Densmore, C. D., unpublished manuscript, Ref. 60-2, Woods Hole Oceanographic Institution (1959).

2 Neumann, A. C., and McGill, D. A., Deep-Sea Res., 8, 223 (1962).

\title{
Anomalous Bottom Water in the Red Sea
}

WATER below $1,000 \mathrm{~m}$ in the Red Sea usually has a potential temperature between 21.5 and $21.6^{\circ} \mathrm{C}$ and a salinity close to $40 \cdot 6$ parts per thousand. But in a small basin around $21^{\circ} 15^{\prime} \mathrm{N}$., $38^{\circ} 05^{\prime} \mathrm{E}$., three research vessels (refs. 1 and 2 and preceding communication) have reported anomalously warm and salty water in the lowest $50 \mathrm{~m}$. In this small basin, the depth of which is almost $2,000 \mathrm{~m}$, the potential temperature reached $25^{\circ} \mathrm{C}$ and the salinity almost 44 parts per thousand.

A fow miles to the south there is a larger basin, the depth of which approaches $2,400 \mathrm{~m}$. A hydrographic station in this basin ( $21^{\circ} 07^{\prime}$ N., $38^{\circ} 10^{\prime} \mathrm{E}$.) was made from R.R.S. Discovery on March 1, 1964. In Fig. 1 the

potential temperature is plotted in relation to the salinity so as to show that the water below $1,500 \mathrm{~m}$ contained the anomalous water much diluted with typical Red Sea deep water.

The anomalous water is clearly not widely distributed, and its origin is not clear. A plausible explanation is that it forms in a very shallow land-locked basin and is transferred across the sill by wind action, then to descend as a density current on the bottom. This is not inconsistent with Jerlov's ${ }^{3}$ report that the anomalous water contains much material in suspension, but it needs to be further examined because of the relatively low oxygen content.

I thank Dr. J. C. Swallow, principal scientist of R.R.S. Discovery when this station was done, for permission to quote these observations in advance of publication.

National Institute of Oceanography, H. Charnock Wormley,

Godalming, Surrey.

× Bruneau, L., Jerlov, N. G., and Koczy, F., Rep. Swedish Deep Sea Expedition, 3, 99 (1953).

${ }^{2}$ Neumann, A. C., and Densmore, C. D., unpublished manuscript, Ref. 60-2, Woods Hole Oceanographic Institution (1959).

${ }^{3}$ Jerlov, N. G., Rep. Swedish Deep Sea Expedition, 3, 71 (1953).

\section{PATTERN OF CELL MIGRATION DURING CORTICAL HISTOGENESIS}

\author{
By Dr. M. BERRY, Dr. A. W. ROGERS and Prof. J. T. EAYRS \\ Department of Anatomy, University of Birmingham, and Institute of Psychiatry, University of London
}

\begin{abstract}
$\mathrm{T}$
HE noural elements of the cerebral cortex are derived by mitotic division from a single germinal layer and attain their definitive arrangement through a process of migration from a juxta-ventricular position towards the superficial cortical surface. Since the classical studies of Tilney ${ }^{1}$ it has been generally accepted that the cortical laminæ are formed by three successive migratory waves, the first giving rise to the supragranular, the second to the granular and the third to the infragranular layers. Recently, however, Berry and Eayrs ${ }^{2}$ were unable to reconcile this concept with the effects of fotal X-irradiation on cortical structure and postulated that the neuro-
\end{abstract}

blasts giving rise to layers $\mathrm{V}$ and VI migrated before those destined to form layers IV, III and II. Quantitative comparisons between nourones of normal and irradiated animals, and comparisons between the development of pyramidal cells in the hippocampus and neocortex, supported this hypothesis. It was suggested that more direct evidence might be obtained from an investigation of the behaviour of neuroblasts labelled with tritiated thymidine.

Each of seven groups of fotal rats, aged 16, 17, 18, 19, 20,21 and 22 days post-coitus respectively, have accordingly been given a single intra-amniotic injection of tritiated thymidine. Animals were killed $4 \mathrm{~h}$ and $2,4,6,8$, 